\title{
Sekolah dengan konsep pendidikan humanis
}

\author{
Sabaruddin Sabaruddin \\ Universitas Islam Negeri Ar-Raniry Banda Aceh, Indonesia \\ Email:sabaruddin@ar-raniry.ac.id
}

\begin{abstract}
Abstrak
Pendidikan adalah tugas dan tanggung jawab bersama untuk mengembangkan kesadaran dan wawasan antar manusia demi kelangsungan kehidupan. Usaha dalam meningkatkan kesadaran, kepribadian anak, serta pengembangan kreativitas melahirkan pendekatan pendidikan yang disebut dengan "humanisasi" dalam proses pendidikan sekarang. Diperlukan usaha untuk menciptakan sekolah yang humanis dalam rangka menciptakan dunia pendidikan yang mardeka bagi murid maupun guru. Pendidikan humanis mempunyai konsep bahwa manusia sebagai subjek yang memiliki kemampuan menghadapi dunia dan lingkungan hidupnya, serta kemampuan untuk mengatasi dan memecahkan masalah-masalah yang akan dihadapi manusia itu sendiri. Sekolah humanis adalah sekolah yang mencintai, memberikebebasan dalam berkreativitas sesuai dengan minat dan bakatnya peserta didik. Tujuan kurikulum humanis harus ada perkembangan pribadi yang dinamis, integritas, dan otonomi sikap kepribadian yang sehat dengan lingkungan. Guru sebagai inisitor, motivator, dan fasilitator dalam menjalan pembelajaran sehingga memecahkan permasalahan-permasalahan. Peserta didik memahami potensi diri mengembangkan potensi dirinya secara positif dan meminimalkan potensi diri yang bersifat negatif.
\end{abstract}

Kata Kunci: Sekolah, Guru, Humanis, Pendidikan 


\section{Abstract}

Education is a shared duty and responsibility to develop awareness and insight between humans to continue life. Efforts to increase awareness, children's personality, and develop creativity gave birth to an educational approach called "humanization" in the current educational process. Efforts are needed to create humanist schools to create a diverse world of education for students and teachers alike. Humanist education has the concept that humans, as subjects, can face the world and their environment, as well as the ability to overcome and solve problems that will be faced by humans themselves. Humanist school is a school that loves and gives freedom in creativity according to students' interests and talents. The humanist curriculum's goal must be dynamic personal development, integrity, and autonomy, healthy personality attitudes to the environment. Teachers, as initiators, motivators, and facilitators, carry out learning to solve students' problems or social problems. Students understand their potential to develop their potential positive and minimize negative selfpotential.

Keywords: School, Teacher, Humanist, Education

\section{Pendahuluan}

Pendidikan merupakan suatu usaha untuk menyiapkan peserta didik melalui kegiatan bimbingan, pengajaran dan latihan dalam perannya di masa yang akan datang. (Hamalik, 2011: 2) Pendidikan juga merupakan aspek universal dalam proses mengubah sikap sekelompok orang melalui upaya pendidikan, pengajaran dan pelatihan, berdasarkan UUSPN No.20 tahun 2003 pendidikan yaitu usaha terencana untuk mewujudkan suasana belajar dan proses pembelajaran yang menjadikan peserta didik lebih aktif mengembangkan potensi dirinya untuk mencapai kecerdasan, kepribadian, akhlak mulia, serta keterampilan yang dibutuhkan oleh masyarakat, bangsa dan negara.

Satu sisi pendidikan merupakan interaksi antarmanusia secara terus menerus, disisi lain pendidikan merupakan interaksi manusia dengan lingkungan dalam meningkatkan dan merubah psikomotorik, kognisi, dan efektif. Pendidikan yaitu tugas dan tanggung jawab untuk mengembangkan kesadaran dan wawasan antar manusia demi kelangsungan kehidupan. Usaha dalam meningkatkan kesadaran, kepribadian anak, serta pengembangan kreativitas melahirkan pendekatan pendidikan yang disebut dengan "humanisasi" dalam proses pendidikan sekarang. Pendidikan harus kembali 
pada wajahnya asli, yaitu suatu proses transformasi nilai yang memanusiakan manusia. (Baharudin \& Makin, 2014:15)

Humanis pada kamus ilmiah popular adalah doktrin yang menekankan pada kepentingan-kepentingan manusia dan ideal (Al-Barry \& AT, 2008: 134). Humanisme merupakan salah satu aliran filsafat yang modern atau "antireligius", pada satu sisi humanis merupakan dukungan yang optimistik terhadap kemampuan manusia atau kemungkinan yang akan terjadi. Filsafat humanisme mempunyai beberapa pandangan hidup yang berpusat pada kebutuhan dan ketertarikan manusia (Mas'ud, 2002:129). Dari sisi Historis "Humanis" berarti suatu gerakan intelektual dan kasustraan yang pertama kali muncul di Italia pada paruh kedua abad ke-14 Masehi (Abidin, 2002:25). Gerakan ini disebut juga dengan gerakan kebudayaan modern, khusus pada kebudayaan Eropa. Tokoh yang disebut sebagai pelaksana gerakan ini antara lain Dante, Boccaceu, Michelangelo, dan Petrarca. Penyimpangan pemahaman antara pemimpin agama dan filosof di masa renaissance mengakibatkan terjadinya pertentangan dan perpisahan antara agama dan humanisme di Barat.

Pendidikan humanisme merupakan sistem pendidikan nasional, pendidikan ini cenderung lebih manusiawi dan mengutamakan komunikasi, dimana jika pendidikan ini terjalin akan menjadi salah satu jembatan dalam membentuk karakter siswa. Pendidikan humanis merupakan salah satu konsep yang sangat strategis untuk meningkatkan kualitas SDM (sumber daya manusia) karena memiliki toleransi yang tinggi antar sesama manusia. Dalam mewujudkan pendidikan yang humanis, maka perlu dukungan penuh dari sekolah dalam menetapkan metode pendidikan humanis sebagai upaya untuk menghapus kekerasan yang terjadi pada sekolah, dimana sekolah merupakan tempat mengembangkan potensi, bakat serta membentuk karakter siswa yang baik (Setiawan, 2019).

Pembelajaran merupakan salah satu proses dalam menjalankan pendidikan, terdapat tiga lingkup komponen dalam membentuk pembelajaran, yaitu pertama; kurikulum, merupakan materi yang akan diajarkan, selanjutnya proses yang menggambarkan bagaimana materi yang akan diajarkan, terakhir produk yaitu hasil dari proses pembelajaran. Instrumen untuk tercapainya tujuan pendidikan adalah kurikulum, kurikulum merupakan pedoman pelaksanaan pembelajaran pada semua jenis tingkat pembelajaran, dengan adanya kurikulum pembelajaran akan terstruktur sehingga dapat meningkatkan prestasi belajar peserta didik.

Guru memiliki peran penting dalam menentukan keberhasilan 
seorang siswa melalui proses pembelajaran, dimana guru harus menciptakan pembelajaran yang kreatif, inovatif, aktif dan efektik. Namun terdapat beberapa kendala yang dihadapi dalam proses pembelajaran berdasarkan konsep pendidikan humanisme yaitu proses pembelajaran siswa lebih fokus pada pengembangan potensi siswa, metode pembelajaran yang dilakukan lebih mengarah pada kemampuan siswa untuk menghafal materi yang diajarkan bukan untuk dianalisis sehingga pengembangan intelektual siswa tidak tercapai dan menciptakan generasi yang pandai secara teoritis bukan yang cerdas dalam menganalisa.

Penerapan konsep pendidikan humanisme pada sekolah juga memiliki beberapa kelebihan, yakni: 1) konsep pendidikan humanisme diterapkan dalam materi pembelajaran untuk pembentukan karakter siswa; 2) berdampak positif pada perkembangan kepribadian siswa, dan; 3) konsep humanisme mengedepankan aspek memanusiakan manusia atau memberi siswa untuk beragumen bebas. Penerapan konsep pendidikan humanisme harus seimbang dengan pengembangan intelektual agar terciptanya keseimbangan antara potensi siswa dengan kemampuan secara intelektual, jika kedua tercapai maka emosi dari siswa akan terkontrol dengan baik. Dengan demikian diperlukan pembahasan tentang bagaimana konsep pendidikan yang humanis, bagaimana lingkunga sekolah yang humanis dan bagaiman kurikulum, kelas, guru, dan peserta didik yang humanis.

\section{Hasil dan Pembahasan}

\section{Pendidikan Humanisme}

Pendidikan merupakan mengarahkan dan menjalankan pengalaman bagi setiap manusia, John Dewey bahwa pendidikan adalah proses rekonstruksi dan reorganisasi pengalaman, dan yang menumbuhkan kemampuan dan mengarahkan jalan pengalaman berikutnya. Pendidikan membutuhkan aktualisasi diri dalam pengalaman yang sudah dilakukan untuk menuju pengembangan masa depan individu. Konsep ini memandang bahwa manusia sebagai subjek dalam menghadapi dunia mempunyai kemampuan dari diri manusia.

Humanis bahasa Latin: humanus berarti manusia dan memiliki arti manusiawi atau sesuai dengan kodrat manusia (Mangunhardjana, 1997: 93). Pendidikan Humanis adalah pendidikan yang bukan hanya mengembangkan 
kualitas kognitif akan tetapi juga mengembangkan psikomotorik dan efektif, sehingga dalam proses pembelajaran nilai kemanusiaan yang terdapat dalam diri peserta didik dapat dikembangkan. Pendidikan yang humanis lebih menekankan bagaimana cara menjalin komunikasi secara personal dan kelompok dalam lingkungan sekolah. Karakter dalam pendidikan humanis dengan asumsi positif yaitu peserta didik mempunyai akal dan sama dalam pengetahuan, untuk mengaktualisasi dirinya peserta didik diberi kebebasan.

Pendapat-pendapat para pakar psikologi tentang pendidikan humanistik: (Arbayah, 2013: 206-207)

\section{Abraham Maslow (1908-1970)}

Abraham Maslow dikenal sebagai peloporaliran psikologi humanistik. Maslow percaya bahwa manusia tergerak untuk memahami dan menerima dirinya sebisa mungkin. Teorinya yang sangat terkenal sampai dengan hari ini adalah teori tentang Hierarchy of Needs (Hirarki Kebutuhan). Menurut Maslow, manusia termotivasi untuk memenuhi kebutuhan-kebutuhan hidupnya. Kebutuhan-kebutuhan tersebut memiliki tingkatan atau hirarki, mulai dari yang paling rendah (bersifat dasar/fisiologis) sampai yang paling tinggi (aktualisasi diri). Hierarchy of needs (hirarki kebutuhan) dari Maslow menyatakan bahwa manusia memiliki lima macam kebutuhan yaitu physiological needs (kebutuhan fisiologis), safety and security needs (kebutuhan akan rasa aman), love and belonging needs (kebutuhan akan rasa kasih sayang dan rasa memiliki), esteem needs (kebutuhan akan harga diri), dan selfactualization (kebutuhan akan aktualisasi diri) (Winkel, 1987: 186).

a) Kebutuhan Fisiologis

Jenis kebutuhan ini berhubungan dengan pemenuhan kebutuhan dasar semua manusia seperti, makan, minum, menghirup udara, dan sebagainya. Termasuk juga kebutuhan untuk istirahat, buang air besar atau kecil, menghindari rasa sakit, dan, seks. Jika kebutuhan dasar ini tidak terpenuhi, maka tubuh akan menjadi rentan terhadap penyakit, terasa lemah, tidak fit, sehingga proses untuk memenuhi kebutuhan selanjutnya dapat terhambat. Hal ini juga berlaku pada setiap jenis kebutuhan lainnya, yaitu jika terdapat kebutuhan yang tidak terpenuhi, maka akan sulit untuk memenuhi kebutuhan yang lebih tinggi.

b) Kebutuhan akan Rasa Aman

Ketika kebutuhan fisiologis seseorang telah terpenuhi secara layak, kebutuhan akan rasa aman mulai muncul Keadaan aman, stabilitas, 
proteksi, dan keteraturan akan menjadi kebutuhan yang meningkat. Jika tidak terpenuhi, maka akan timbul rasa cemas dan takut sehingga dapat menghambat pemenuhan kebutuhan lainnya.

c) Kebutuhan akan Rasa Kasih Sayang

Ketika seseorang merasa bahwa kedua jenis kebutuhan di atas terpenuhi, maka akan mulai timbul kebutuhan akan rasa kasih sayang dan rasa memiliki. Hal ini dapat terlihat dalam usaha seseorang untuk mencari dan mendapatkan teman, kekasih, anak, atau bahkan keinginan untuk menjadi bagian dari suatu komunitas tertentu seperti tim sepakbola, klub peminatan, dan seterusnya. Jika tidak terpenuhi, maka perasaan kesepian akan timbul.

d) Kebutuhan akan Harga Diri

Kemudian, setelah ketiga kebutuhan di atas terpenuhi, akan timbul kebutuhan akan harga diri menurut Maslow, terdapat dua jenis, yaitu lower one dan higher one. Lower one berkaitan dengan kebutuhan seperti status, atensi, dan reputasi. Sedangkan higher one berkaitan dengan kebutuhan akan kepercayaan diri, kompetensi, prestasi, kemandirian, dan kebebasan. Jika kebutuhan ini tidak terpenuhi, maka dapat timbul perasaan rendah diri dan inferior.

e) Kebutuhan akan Aktualisasi Diri

Kebutuhan terakhir menurut hirarki kebutuhan Maslow adalah kebutuhan akan aktualisasi diri. Jenis kebutuhan ini berkaitan erat dengan keinginan untuk mewujudkan dan mengembangkan potensi diri. Menurut Abraham Maslow, kepribadian bisa mencapai peringkat teratas ketika kebutuhan-kebutuhan primer ini banyak mengalami interaksi satu dengan yang lain, dan dengan aktualisasi diri seseorang akan bisa memanfaatkan faktor potensialnya secara sempurna.

Dari penjelasan diatas disimpulkan pendidikan humanisme yaitu pendidikan yang harus mencapai ke-5 kebutuhan tersebut.

\section{Carl Ransom Rogers (1902-1987)}

Carl Rogers adalah seorang psikolog humanistik yang menekankan perlunya sikap saling menghargai dan tanpa prasangka dalam membantu kepribadian seseorang mengatasi masalah kehidupan. Carl Rogers menyakini masukan yang ada pada diri seseorang sesuai dengan pengalamannya dan secara mutlak mengarah pada pemenuhan kebutuhan dirinya sendiri. Menurut Rogers dalam Budi Agus Sumantri, ada dua tipe 
belajar, yaitu kognitif (kebermaknaan) dan eksperimental (pengalaman). Guru memberikan makna (kognitif) bahwa tidak membuang sampah sembarangan dapat mencegah terjadinya banjir. Jadi, guru perlu menghubungkan pengetahuan akademik ke dalam pengetahuan kognitif (Sumantri \& Ahmad, 2019: 13). Rogers menegaskan, dalam pengembangan diri seorang pribadi akan berusaha keras demi aktualisasi diri (self actualisation), pemeliharaan diri (self maintenance), dan peningkatan diri (self inhancement) (Arbayah, 2013: 207).

Perspektif para humanis terlihat sebagai penempatan sebab pelaku ('illaf fai'iliah) dan sebab tujuan ('illah ghayah) di dalam diri manusia sehingga individu bisa mengaktualisasikan segenap potensi dirinya tidak hanya dalam bentuk yang terasing dari sebab-sebab di luar, tetapi bahkan juga dalam posisi yang mengemban tujuan dari perwujudan dirinya, dan individu ini sepenuhnya bertumpu pada dirinya sendiri dalam proses aktualisasi diri, pemeliharaan diri, dan peningkatan diri (Arbayah, 2013:207).

Rogers menyatakan ada lima hal yang penting dalam proses belajar humanisme, yaitu: (Siregar, 2011: 37)

a) Hasrat untuk belajar: keinginan untuk belajar dikarenakan adanya dorongan rasa ingin tahu manusia yang terus menerus terhadap dunia sekelilingnya. Dalam proses memecahkan jawabannya, seorang individu mengalami kegiatan-kegiatan belajar.

b) Belajar bermakna: seseorang yang beraktivitas akan selalu mempertimbangkan apakah aktivitas tersebut mempunyai makna bagi dirinya. Jika tidak, tentu tidak akan dilakukannya.

c) Belajar tanpa hukuman merupakan belajar yang terlepas dari hukuman atau ancaman menghasilkan anak bebas untuk melakukan apa saja, dan mengadakan percobaan hingga menemukan sendiri suatu hal yang baru.

d) Belajar dengan daya usaha atau inisiatif sendiri: menunjukkan tingginya motivasi internal yang dimiliki. Siswa yang banyak inisiatif, akan mampu untuk memandu dirinya sendiri, menentukan pilihannya sendiri dan berusaha mempertimbangkan sendiri hal yang baik bagi dirinya.

e) Belajar dan perubahan: keadaan dunia terus berubah, karena itu peserta didik harus belajar untuk dapat menghadapi serta menyesuaikan kondisi dan situasi yang terus berubah. Dengan begitu belajar yang 
hanya mengingat fenomena atau menghafal kejadian dianggap tak cukup.

\section{Pendidikan Humanisme dalam Lingkungan Sekolah}

Aktivitas belajar salah satu kebutuhan manusia. Belajar bisa diartikan aktivitas memperoleh pengetahuan dari orang yang dianggap lebih tahu kepada orang yang kurang tahu. Pendidikan merupakan salah satu usaha dalam menumbuhkan dan mengembangkan prestasi dan potensi seseorang yang sesuai dengan hakikat dan nilai-nilai kemanusiaan dan kebudayaan. Pendidikan merupakan segala sesuatu dalam kehidupan yang mempengaruhi pembentukan berpikir dan bertindak individu (Soyomukti, 2010: 29). Pendidikan dalam arti yang khusus yaitu pengajaran yang diselenggarakan di sekolah sebagai tempat mendidik, agar memiliki kemampuan kognitif, kesiapan mental, kesadaran yang berguna bagi masyarakat, menjalin hubungan sosial sesama, dan memiliki tanggung jawab pribadi dan masyarakat (Soyomukti, 2010: 40-41).

Teori pendidikan humanistik yang muncul pada tahun 1970-an bertolak dari tiga teori filsafat, yaitu: pragmatisme, progresivisme dan eksistensisalisme. (Knight, 1982: 82). Ide utama pragmatisme dalam pendidikan adalah memelihara keberlangsungan pengetahuan dengan aktivitas yang dengan sengaja mengubah lingkungan (Dewey, 1966: 344). Pragmatisme melihat pendidikan sebagai kehidupan dalam ruang lingkup belajar yang demokratis dan menjadikan semua orang berpartisipasi dalam membuat keputusan. Pengaruh dari pemikiran pragmatisme menjadi faktor utama lahirnya pendidikan yang progresivisme dan humanisme. Pragmatisme dalam pendidikan adalah bahwa: (1) Peserta didik (siswa) adalah subjek yang memiliki pengalaman. (2) Guru bukan orang yang tahu kebutuhan siswa untuk masa depannya. (3) Materi/ kurikulum harus sesuai kebutuhan siswa yang menekankan proses daripada materi. (4) Metode pembelajaran harus memberikan kebebasan kepada siswa untuk mencari pengalaman belajar yang berguna. (5) Kebijakan pendidikan mengikuti arus perubahan sosial (Arbayah, 2013: 208).

Pendidikan Amerika sejak tahun 1920-1950-an menjadikan pendidikan yang progresivisme sebagai teori dominan, disebabkan oleh kuatnya pengaruh, knight mencatat, dan alasan hilangnya eksistensi teori dikarenakan program, ide, dan gagasan pendidikan progresif yang telah dikembangkan oleh teori lain. Pendidikan progresivisme dikembangkan pada pendidikan humanisme. Pengaruh terakhir lahirnya pendidikan humanisme karena eksistensialisme, 
teori ini menekankan pada keunikan dari individual seorang anak. Keunikan yang terdapat pada diri seorang anak yang menjadikan pendidikan humanis upaya mencari jati diri seorang anak dan membantu seorang anak bebas dan bertanggung jawab dalam memilih, dengan adanya kebebasan maka akan membantu seorang anak dalam mengembangkan potensinya secara maksimal.

Teori belajar humanistik juga menitikberatkan pada metode studentcentered, dengan menggunakan "komunikasi antar pribadi" yaitu berpusat pada peserta didik dengan mengembangkan potensi-potensi yang dimiliki peserta didik untuk dapat mengatasi permasalahan yang dihadapi dalam suatu kehidupan. Dewantara (1962: 14-15), menyatakan bahwa tujuan pendidikan adalah supaya dapat memajukan kesempurnaan hidup peserta didik, yaitu selaras dengan kodratnya, serasi dengan adat-istiadat, dinamis, memperhatikan sejarah bangsa dan membuka diri pada pergaulan dengan kebudayaan lain. Yang terpenting dari adalah proses suasana (emotional approach) dalam pembelajaran bukan hasil dari belajar. Seorang guru harus lebih responsif terhadap kebutuhan kasih sayang dalam proses pendidikan.

\section{Kurikulum Pendidikan Humanis}

Kurikulum sebagai penyedia pengalaman dalam memperlacar perkembang siswa. Oleh karena itu, kurikulum merupakan alat untuk mencapai tujuan pendidikan dan sekaligus sebagai pedoman dalam pelaksanaan pengajaran pada semua jenis dan jenjang pendidikan. Aktifitas selama proses pembelajaran siswa berperan sebagai pelaku utama (student center) yang memaknai proses pengalaman belajarnya sendiri (Salahudin, 2011). Diharapkan siswa memahami potensi diri, mengembangkan potensi dirinya secara positif dan meminimalkan potensi diri yang bersifat negatif. Tujuan pembelajaran lebih kepada proses belajarnya daripada hasil belajar. Menurut Sadulloh adapun proses yang umumnya dilalui dalam teori Humanisme adalah.

a. Merumuskan tujuan belajar yang jelas

b. Mengusahakan partisipasi aktif siswa melalui kontrak belajar yang bersifat jelas, jujurdan positif.

c. Mendorong siswa untuk mengembangkan kesanggupan siswa untuk belajar atas inisiatif sendiri

d. Mendorong siswa untuk peka berpikir kritis, memaknai proses pembelajaran secara mandiri 
e. Siswa di dorong untuk bebas mengemukakan pendapat, memilih pilihannya sendiri, melakukkan apa yang diinginkan dan menanggung resiko dari perilaku yang ditunjukkan.

f. Guru menerima siswa apa adanya, berusaha memahami jalan pikiran siswa, tidak menilai secara normatif tetapi mendorong siswa untuk bertanggungjawab atas segala resiko perbuatan atau proses belajarnya.

g. Memberikan kesempatan murid untuk maju sesuai dengan kecepatannya

h. Evaluasi diberikan secara individual berdasarkan perolehan prestasi siswa.

i. Bentuk aplikasi humanisme dalam pembelajaran berisi bagai mana cara berupaya menggabungkan keterampilan dan informasi kognitif, dengan segi-segi efektif, nilai-nilai dan prilaku antar pribadi. Sehubungan dengan itu dibawah ini akan diterangkan beberapa program dalam aplikasi humanisme dalam pembelajaran.

Kurikulum harus terakarakteristik yang berkenaan dengan tujuan, metode, organisasi, dan evaluasi. Tujuan kurikulum humanis harus ada perkembangan pribadi yang dinamis, integritas, dan otonomi sikap kepribadian yang sehat dengan lingkungan. Perkembangan aspek diri mulai dari kognitif, estetika dan moral dalam mencapai keseimbangan dengan mengaktulisasi diri. Apabila manusia memiliki karakter yang baik maka dia dapat berkerja dengan baik dalam lingkungannya.

\section{Implementasi Pendidikan Humanisme}

1. Model Pendidikan Humanisme

Pada model pendidikan humanisme memerlukan siswa yang unik dan aktif, sehingga mengusahakan siswa aktif berpatisipasi dalam kelas. Ada beberapa model Pendidikan yang humanisme antara lain:

a) Student Centered Learning

Konsep ini sesuai dengan konsep pembelajaran Carl Rogers yaitu: a) Memfasilitasi orang lain tanpa mengajar; b) Memperkuat diri dengan belajar secara signifikan; c) Belajar tanpa tekanan, dan d) Mendidik dan mengajarkan siswa secara signifikan tanpa tekanan, dan memfasilitasi perbedaan yang ada. 
b) Humanizing of The Classroom

Model pendidikan ini dilatarbelakangi oleh kondisi sekolah yang otoriter, sehingga mengakibatkan siswa meninggalkan pendidikan. Model pendidikan berpedoman pada tiga hal yaitu menyadari diri yang merupakan proses pertumbuhan, perubahan, dan perkembangan yang terus berubah, menggali konsep identitas diri, dan membuka jalan berfikir yang luas. Perubahan yang dilakukan bukan hanya pada materi tetapi pada aspek metodologis yang dipandang manusiawi.

c) Active Learning

Model Pendidikan ini gagasan dari M. L. Siberman yang mana belajar bukanlah konsekuensi otomatis dalam menyampaikan informasi pada siswa, akan tetapi belajar melibatkan tindakan dan mental sekaligus. Pendidikan active learning yaitu pendidikan yang dilakukan dengan cara mendengar, melihat dan mendiskusikan maka akan memperoleh pengetahuan dan keterampilan dalam menguasai pelajaran.

d) Quantum Learning

Quantum Learning menggabungkan sugestiologi, teknik pemercepatan belajar dan neurolingusitik dengan teori, keyakinan, dan metode tertentu. (Hernacki \& de Porter, 2004: 16) Asumsi Quantum Learning dalam belajar siswa harus mampu menggunakan potensi nalar dan emosi secara tepat.

e) Quantum Teching

Model pendidikan yang mengajak siswa lebih aktif dalam proses pembelajaran sehingga menciptakan suasana yang tidak membosankan, dimana guru mampu berinteraksi dalam membawa potensi fisik, emosi, dan psikis siswa menjadi sesuatu yang integral. Model pendidikan Quantum Teching yakni guru harus mampu melibatkan siswa baik itu dari segi pikiran, bahasa tubuh dan perasaan dalam ranah pendidikan.

f) The Accelerated Learning

Guru mampu melakukan metode pendekatan pembelajaran misalnya belajar dengan metode animasi, belajar dengan cara visual, belajar dengan cara menggambarkan dan mengamatinya, dan belajar dengan cara diskusi memecahkan masalah yang ada dan melakukan refleksi seperti mengajukan tanya jawab, sehingga membuat kelas aktif dan dapat mengembangkan wawasan siswa. Ada beberapa proses 
belajar yang harus dilalui antara lain:

1) Merumuskan tujuan belajar yang jelas

2) Partisipasi aktif siswa yang bersifat positif, jelas dan jujur

3) Memotivasi siswa dalam mengembangkan potensi.

4) Memotivasi siswa agar berfikir lebih kritis.

5) Siswa bebas mengungkapkan pendapatnya sendiri, melakukan apa yang diinginkan serta bertanggung jawab terhadap apa yang dilakukannya. Guru menghargai atas rasio siswa, mengajak siswa untuk bertanggung jawab atas apa yang dilakukannya.

6) Memberi kesempatan siswa untuk berkembang sesuai dengan perkembangan.

7) Penilaian diberikan sesuai dengan prestasi siswa

8) Penilaian dilakukan sesuai prosesnya, dimana guru menilai siswa setiap kali pertemuan (tatap muka) dengan siswanya (Chatib, 2009: 159)

2. Kelas

Prinsip pengelolaan kelas adalah pengendalian perilaku siswa, untuk mendukung itu, maka perlu aturan dan panduan bagi siswa tentang bagaimana mereka berperilaku, seperti kapan dan bagaimana mereka boleh mengintrupsi guru, duduk dan bergerak, dan sebagainya. Prinsip dasar humanisme adalah proses pembelajaran dengan mendekatkan pendidikan humanis di kelas. Terdapat beberapa ciri aplikasi pembelajaran humanistik di kelas antara lain:

a. Memberi kesempatan seluasnya agar siswa mengembangkan diri secara potensi, pribadi, sikap, berkembang menuju taraf yang lebih baik/ sempurna.

b. Adanya proses pemanusiaan manusia

c. Siswa memiliki peran, dan

d. Proses yang berlangsung adalah pembelajaran bukan pengajaran (Riyanton, 2019).

Ruang kelas yang humanisme siswa diberi kebebasan dorongan ingin tahu, untuk memenuhi minat dan menemukan apa yang penting dan berarti di dunia disekitarnya.

3. Guru 
Guru berusaha untuk memenuhi kebutuhan akan rasa aman, kasih sayang, self steem dan aktualisasi diri (Sriyanti, 2011: 86). Perspektif humanistik, pendidik harus memperhatikan pendidikan yanglebih responsif terhadap kebutuhan afektif siswa, kebutuhan afektif adalah kebutuhan yang berhubungan dengan emosi, perasaan, nilai, sikap, predisposisi, dan moral (Djiwandono, 2006: 181). Guru yang efektif tampaknya adalah guruguru yang manusiawi. Mereka mempunyai rasa humor, adil, menarik, lebih demokratis daripada autokratik, dan mereka mampu berhubungan dengan mudah dan wajar dengan para siswa, baik secara perorangan ataupun secara kelompok (Ahmadi \& Widodo. 2013: 237).

Ciri-ciri guru yang efektif dalam pendidikan humanisme antara lain:

a. Guru yang mempunyai persepsi bahwa siswanya mampu memecahkan masalah mereka sendiri dengan baik

b. Guru yang memprediksi bahwa siswanya mempunyai sifat ramah, bersahabat serta memiliki sifat ingin berkembang.

c. Guru yang menghargai siswanya.

d. Guru yang mempunyai persepsi bahwa siswanya dapat mengembangkan ilmu pengetahuan dari dalam dirinya sendiri, dia melihat siswanya mempunyai kreativitas dan dinamika dan bukan orang yang pasif.

e. Guru yang menganggap pada dasarnya siswa dapat dipercaya dan dapat diandalkan.

f. Guru yang memandang siswanya dapat memenuhi dan meningkatkan dirinya. (Ahmadi \& Widodo. 2013: 238)

Dapat di simpulkan peran guru dalam pendidikan humanisme adalah melakukan segala sesuatu untuk membangun siswa dalam self concept, dalam arti lainnya guru dapat melibatkan siswa dalam proses belajar sehingga siswa merasa dihargai, dikagumi, berpengalaman dan sebagainya. Menurut Zakiah Daradjat "guru yang sukses adalah guru yang memilih bagi anak didiknya pekerjaan yang sesuai dengan kemampuan tubuh dan mentalnya. Dalam proses mengajar, guru harus memperhatikan keadaan murid, tingkat pertumbuhan dan perbedaan perorangan yang terdapat di antara mereka" (Daradjat, 2005: 15). Guru yang humanis belajar bukan hanya dari guru akantetapi dari siswa juga, memiliki hubungan yang baik dengan siswa, memberi dorongan kepada siswa dengan saling percaya.

4. Siswa 
Siswa adalah seseorang yang mempunyai pengalaman (Knight, 1982: 66). Seorang individu yang berpengalaman yaitu mampu menggunakan kecerdasannya dalam memecahkan situasi problematik. Pendidikan humanis membantu siswa dalam mengembangkan dirinya sesuai dengan potensinya, bimbingan yang tidak mengekang siswa dalam proses pembelajaran mempermudah penanaman nilai-nilai yang memberi informasi mengenai hal yang positif dan negatif. Proses dapat belajar berjalan lancar apabila siswa dapat menguji kemampuannya, pengalaman baru dengan membuat kesalahan-kesalahan tanpa mendapat ancaman yang dapat menyinggung perasaannya. Belajar atas inisiatif siswa sendiri dapat memusatkan perhatian siswa baik pada proses maupun terhadap hasil belajar.

Kebebasan yang diusung dalam pendidikan humanis adalah kebebasan yang bebas nilai. Kebebasan dalam segala aspek kehidupan. Peserta didik berperan sebagai pelaku utama (student center) yang memaknai proses pengalaman belajarnya sendiri. Diharapkan peserta didik memahami potensi diri mengembangkan potensi dirinya secara positif dan meminimalkan potensi diri yang bersifat negative.

\section{Kesimpulan}

Pendidikan humanis mempunyai konsep bahwa manusia sebagai subyek yang memiliki kemampuan menghadapi dunia dan lingkungan hidupnya, serta kemampuan untuk mengatasi dan memecahkan masalah-masalah yang akan mengancam manusia itu sendiri. Sekolah humanis adalah sekolah yang mencintai, memberi kebesbasan dalam berkreatifitas sesuai dengan minat dan bakatnya peserta didik. Tujuan kurikulum humanis harus ada perkembangan pribadi yang dinamis, integritas, dan otonomi sikap kepribadian yang sehat dengan lingkungan. Guru sebagai inisitor, motivator, dan fasilitator dalam menjalankan pembelajaran untuk memecahkan permasalah-permasalahan. Peserta didik memahami potensi diri mengembangkan potensi dirinya secara positif dan meminimalkan potensi diri yang bersifat negative.

\section{Daftar Pustaka}

Abidin, Z. (2002). Filsafat manusia. Bandung: Remaja Rosdakarya.

Ahmadi, H. A. \& Supriyono, W. (2013). Psikologi belajar. Jakarta: Rineka Cipta. Al-Barry, M.D.J., \& AT, S. H. (2008). Kamus ilmiah kontemporer, Bandung: 
Pustaka Setia.

Arbayah. A. (2013). Model pembelajaran humanistik. Dinamika Ilmu, 13(2). 204-220. https://doi.org/10.21093/di.v13i2.26

Baharudin, B. \& Makin. M. (2014). Pendidikan humanistik, konsep, teori, dan aplikasi dalam dunia pendidikan. Yogyakarta: Ar-Ruzz.

Chatib, M. (2009). Sekolahnya manusia. Bandung: Mizan Pustaka.

Daradjat, Z. (2005). Kepribadian guru. Jakarta: Bulan Bintang.

Dewantara, K. H. (1962). Karja. Madjelis Luhur Persatuan Taman Siswa.

Dewey, J. (1966). Democracy and education (1916). Jo Ann Boydston (ed.). The Middle Works of John Dewey, 9, 1899-1924.

Djiwandono, S. E. W. (2006). Psikologi pendidikan. Jakarta: PT. Gramedia Widiasarana Indonesia.

Farida, Y. E. (2015). Humanisme dalam pendidikan Islam. Tarbawi, Jurnal Pendidikan Islam. 12 (1). 105-120. https://doi.org/10.34001/tarbawi. v12i1.306.

Hamalik, O. (2011). Kurikulum dan pembelajaran. Jakarta: Bumi Aksara.

Hernacki, M. \& de Porter. B. (2004). Quantum learning, terjemahan oleh Alwiyah Abdurrahman. Bandung: Mizan Pustaka.

Knight, G R. (1982). Issues and alternatives in educational philosophy. Michigan: Andrews University Press.

Mangunhardjana, A. (1997). Isme-isme dalam etika dari A sampai Z. Yogyakarta: Kanisius.

Mas'ud, A. (2002). Menggagas format pendidikan nondikotomik (Humanisme religius sebuah paradigma pendidkan Islam. Yogyakarta: Gama Media..

Riyanton, M. (2019). Implementasi metode pembelajaran bahasa untuk guru sekolah dasar. Dinamika Journal: Pengabdian Masyarakat, 1(1). 1-13.

Rogers, C. R. (1982). Freedom to learn for the 80's. California: Charles E. Meril Publishing Company

Sadulloh, U. (2008). Pengantar filsafat pendidikan. Bandung: Alfabeta.

Sagala, S. (2011). Konsep dan makna pembelajaran. Bandung:ALFABETA

Salahudin, S. (2011). Filsafat pendidikan. Bandung: CV. Pustaka.

Setiawan, A. (2019). Hapus kekerasan di sekolah melalui pendidikan humanis. Media Indonesia. 5 Mei. 
Humanika, Kajian IImiah Mata Kuliah Umum, Vol. 20. No. 2. (2020), 147-162

Siregar, E. (2011). Teori belajar dan pembelajaran. Bogor: Penerbit Ghalia Indonesia.

Soyomukti, N. (2010). Teori-teori pendidikan, tradisional, (neo)liberal, marxis-sosialis, postmodern, Yogyakarta: Ar-Ruzz Media.

Sriyanti, L. (2011). Psikologi belajar. Yogyakarta: Ombak.

Sumantri, B. A \& Ahmad. N. (2019). Teori belajar humanistik dan implikasinya terhadap pembelajaran pendidikan agama Islam. Fondatia, 3(2), 1-18.

Winkel, W.S. (1987). Psikologi pengajaran, Jakarta: Gramedia. 